\title{
Squamous Plaque/Cyst
}

National Cancer Institute

\section{Source}

National Cancer Institute. Squamous Plaque/Cyst. NCI Thesaurus. Code C154894.

A focus of squamous epithelium in or near the surface of the heart, generally believed to be an embryonic rest. 